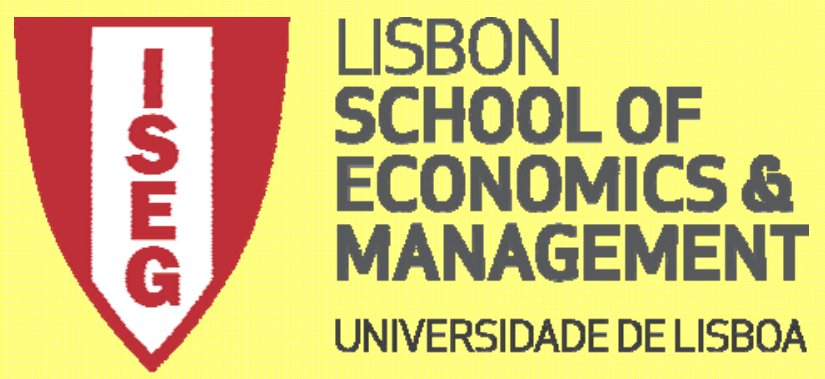

Department of Ec onomics

\author{
António Afonso \& Miguel St. Aubyn \\ Economic Growth and Public and \\ Private Investment Returns
}

WP14/2016/DE/UECE

WORKING PAPERS

ISSN 2183-1815

U

LISBOA

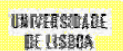




\title{
Economic Growth and Public and Private Investment Returns*
}

\author{
António Afonso \# and Miguel St. Aubyn ${ }^{\#}$
}

\begin{abstract}
We study the macroeconomic effects of public and private investment in 17 OECD economies through a VAR analysis with annual data from 1960 to 2014. From impulse response functions we find that public investment had a positive growth effect in most countries, and a contractionary effect in Finland, UK, Sweden, Japan, and Canada. Public investment led to private investment crowding out in Belgium, Ireland, Finland, Canada, Sweden, the UK and crowding-in effects in the rest of the countries. Private investment has a positive growth effect in all countries; crowds-out (crowds-in) public investment in Belgium and Sweden (in the rest of the countries). The partial rates of return of public and private investment are mostly positive.
\end{abstract}

JEL: C32, E22, E62

Keywords: fiscal policy, public investment, private investment, impulse response functions, VAR

\footnotetext{
* We thank Narcissa Balta and participants at the DG ECFIN Workshop on "Fiscal policy after the crisis" $19^{\text {th }}$ January 2016, Brussels, for useful comments and suggestions. The opinions expressed herein are those of the authors and do not necessarily reflect those of their employers.

\# ISEG/ULisbon - University of Lisbon, Department of Economics; UECE - Research Unit on Complexity and Economics, R. Miguel Lupi 20, 1249-078 Lisbon, Portugal. UECE is supported by FCT (Fundação para a Ciência e a Tecnologia, Portugal). Emails: aafonso@iseg.utl.pt; mstaubyn@iseg.utl.pt.
} 


\section{Introduction}

The 2008-2009 financial and sovereign debt crisis led to a substantial drop in both GDP and investment levels and growth rates. Moreover, it led to substantial changes in economic policy, namely budgetary policy. Under budgetary duress, the level of government indebtedness is deemed to have a negative impact on public investment in EMU member countries (see, for instance, Turrini, 2004, for the cases in the 1980s and in the 1990s). In fact, the abovementioned changes took in several countries the form of reduced expenditure, including public investment, and increased taxation. It is expectable that these changes may well constitute a policy regime change with structural implications on previous estimations regarding the relevance of investment for long-term growth.

Additionally, such policy changes, and especially in countries following adjustment programs, came with an emphasis on structural reforms that concern public spending levels and structure, and more generally, the way the economy and markets operate. It becomes then important to test if macroeconomic efficiency changes effectively occurred, and in what direction. For instance, Afonso and Jalles (2015) argue that the relevance of fiscal components differs for private and public investment developments.

Understanding and measuring linkages between public and private investment and economic growth are of crucial importance both in developed economies and emerging markets. Public investment is a part of public expenditure and decisions are taken within the larger framework of public finance. At the same time, it constitutes an addition to public capital. The latter, together with private and human capital, labour and other inputs, is in several approaches considered as a production factor. Public investment may therefore be linked to growth prospects. However, and as it is well documented in the literature, as part of public expenditure, it may crowd other types of investment, namely private, so that in some circumstances the net impact of public investment on GDP may be negative (see, for instance, Dreger and Reimers, 2014, Cavalcanti, et al., 2014, IMF, 2014).

At the same time, note the importance of public investment in the fiscal surveillance mechanisms of the EU, where $\mathrm{n}^{\circ} 3$ of Article 126 of the Treaty of the European Union (TEU, 2012) reads:

"If a Member State does not fulfil the requirements under one or both of these criteria, the Commission shall prepare a report. The report of the Commission shall also take into account whether the government deficit exceeds government investment expenditure and 
take into account all other relevant factors, including the medium-term economic and budgetary position of the Member State",

which indicates the preference for some Golden Rule based approach for public investment.

Moreover, the EC (2015) presented a new Investment Plan for Europe in support of its investment, structural reforms and fiscal responsibility strategy. Once more, the emphasis on investment is stressed, and a European Fund for Strategic Investments (EFSI) is created to promote the European Commission's Investment Plan for Europe, where it is mentioned that "co-financed expenditure should not substitute for nationally financed investments, so that total public investments are not decreased." 1

In this paper we contribute to the literature by using a VAR analysis for 17 OECD countries between 1960 and 2014 to assess the effects of public and private investment in terms of economic growth, crowding out and crowding in effects. In that context, we also compute public and private investment macroeconomic rates of return, and assess the potential effect of the 2008 economic and financial crisis, by comparison with previous shorter time span research, obtained before the crisis.

Our analysis provides notably the following results: public investment had a positive growth effect in most countries, and a contractionary effect on output in Finland, UK, Sweden, Japan, and Canada; positive public investment impulses led to private investment crowding-out in Belgium, Ireland, Finland, Canada, Sweden, the UK and crowding-in effect on private investment in the rest of the countries; private investment had a positive growth effect in all countries; private investment crowds-out public investment in Belgium and Sweden and crowds-in public investment in the remainder of the countries.

Moreover, the partial rate of return of public investment is mostly positive and the partial rate of return of private investment is only negative in Greece and marginally in Belgium.

The paper is organized as follows. In Section 2 we briefly review the literature and previous results. Section 3 outlines the analytical framework. In Section 4 we present and discuss our results. Section 5 is the conclusion.

\footnotetext{
${ }^{1}$ Regarding the so-called Juncker plan Le Moigne et al. (2016) argue, in the context of an estimated DSGE model of the Eurozone economy, that it would have had a positive growth impact if it had been implemented at the beginning of the global economic and financial crisis.
} 


\section{Literature}

There are several techniques and results that allow for crowding in and crowding out effects of public investment (see Afonso and St. Aubyn, 2009, 2010). Namely, and within a vector auto regression analysis, different rates of return are estimated. The total investment rate of return takes into account both private and public investment costs, while a partial rate of return only considers public investment as compared to GDP returns.

In Afonso and St. Aubyn (2009, 2010), the extent of crowding in or crowding out of both components of investment was assessed and the associated macroeconomic rates of return of public and private investment for each country were computed from impulse response functions. Results showed the existence of positive effects of public investment and private investment on output. Crowding in effects of private investment on public investment were more generalized then the reverse case.

These regularities are likely to be affected by major policy changes after 2009 , namely due to the financial and sovereign debt crisis. In this project we intend to make further progress in this area of research, namely by studying the impact of the recent financial and sovereign debt crisis on the linkages between public and private investment and economic growth.

IMF (2015) documents the private investment contraction in advanced economies during and after the economic and financial crisis. The "overall weakness of economic activity" is found to be the most important factor accounting for this shrinking. Our empirical modelling clearly encompasses this important channel, as private investment may react contemporaneously and/or with lags to GDP, to public investment, to taxes and to interest rates.

Some recent research provides evidence that more stringent financial conditions affect both how the economy reacts to public spending and investment and how investment responds to the economy. For the specific case of Japan, and using panel data techniques, Brückner and Tuladhar (2014) show that financial distress has a significant negative effect on the local government spending multiplier, while economic slack has a positive effect. For instance, Abiad et al. (2015) for 17 OECD economies report, via model simulations, that increasing public investment increases real growth and has a crowding-in effect on private investment.

In addition, and in the same vein, but also with a VAR methodology Dreger and Reimers (2014) refer that, and in what concerns the euro area, public investment decreases could have adversely affected private investment and GDP. In an interesting variation, $\mathrm{Xu}$ and Yan 
(2014) study crowding in and crowding out effects in China. They also resort to VAR analysis, and divide public capital formation in investment in public goods and infrastructure provision and investment involved in the private goods. Results suggest that the first crowds in private investment while the latter leads to crowding out.

The reader may also refer to our earlier work for further references on this subject.

Pereira (2000) introduced the estimation of macroeconomic rates of return for public investment. His VAR-based methodology was further developed by Pina and St. Aubyn (2005, 2006), who proposed the distinction between a partial and a total-cost rate of return. This research team, in Afonso and St. Aubyn (2009, 2010), estimated these rates of return for industrialized countries and also computed private investment rates of return, and extended previous research by considering a more complete VAR, by computing confidence bands and by generally presenting more detailed explanations and results.

\section{Analytical framework}

\section{The VAR model}

We estimate a five-variable VAR model for each country throughout the period 19602014 using annual data. As in Afonso and St. Aubyn (2010), where more detailed explanations may be found, we include five endogenous variables: the logarithmic growth rates of real public investment, Ipub, real private investment, Ipriv, real output, $Y$, real taxes, Tax, and real interest rates, $R$.

The VAR lag length is determined by the usual information criteria.

The VAR is identified by means of a Cholesky decomposition. Variables are ordered from the most exogenous variable to the least exogenous one, public investment being the "most exogenous". By construction, structural shocks to private investment, GDP, taxes and the real interest rate affect public investment with a one-period lag. Private investment responds to public investment in a contemporaneous fashion, and to shocks to other variables with a lag.

The VAR model in standard form can be written as

$$
X_{t}=c+\sum_{i=1}^{p} A_{i} X_{t-i}+\varepsilon_{t}
$$

where $X_{t}$ denotes the $(5 \times 1)$ vector of the five endogenous variables given by $X_{t} \equiv\left[\begin{array}{llll}\Delta \log \text { Ipub }_{t} \quad \Delta \log \text { Ipriv }_{t} \quad \Delta \log Y_{t} \quad \Delta \log \text { Tax }_{t} \quad \Delta R_{t}\end{array}\right]^{\prime}, c$ is a $(5 \times 1)$ vector of intercept terms, $A_{i}$ is the matrix of autoregressive coefficients of order $i$, and the vector of random 
disturbances $\varepsilon_{t} \equiv\left[\begin{array}{lllll}\varepsilon_{t}^{I p u b} & \varepsilon_{t}^{I p r i v} & \varepsilon_{t}^{Y} & \varepsilon_{t}^{T a x} & \varepsilon_{t}^{R}\end{array}\right]^{\prime}$ contains the reduced form OLS residuals. The lag length of the endogeneous variables, $p$, will be determined by the usual information criteria.

\section{Macroeconomic rates of return}

We compute four different rates of return: $r_{1}$, the partial rate of return of public investment; $r_{2}$, the rate of return of total investment (originated by an impulse to public investment); $r_{3}$, the partial rate of return of private investment; $r_{4}$, the rate of return of total investment (originated by an impulse to private investment).

These rates are derived from the VAR impulse response functions, as explained in Afonso and St. Aubyn (2009). In the following lines we provide the economic interpretation to these variables.

The partial rate of return of public investment, $r_{l}$, compares a (partial) cost, public investment, to a benefit, GDP change, following an impulse to public investment.

The rate of return of total investment (originated by an impulse to public investment), $r_{2}$, compares the total cost (public plus induced private investment), to the same benefit, GDP change. If more public capital induces more private investment, we will call this a crowding in case, and $r_{1}$ will exceed $r_{2}$. Moreover, if a positive impulse in public investment leads to a private investment decrease, than $r_{1}$ will be smaller than $r_{2}$.

In some cases a positive impulse to public investment will lead to a decrease in GDP. In those occasions it will not be feasible to compute a rate of return. Note that a negative rate of return will arise when the benefits, albeit positive, are smaller than costs.

The rates of return $r_{3}$ and $r_{4}$ concern the measurement of consequences to positive impulses in private investment. As in the case of public investment impulses, we may have that private investment leads to the crowding in of public investment, or else that government reacts to private investment impulse by diminishing capital formation (the crowding out case). In the latter case, $r_{3}$ will be smaller than $r_{4}$. The detailed analytics of the computation of the macroeconomic rates of return are summarised in Appendix 1. 


\section{Empirical analysis}

\section{Data set}

We use annual data for 14 EU countries (sample in parenthesis): Austria (1965-2014), Belgium (1970-2014), Denmark (1971-2014), Germany (1970-2014), Finland (1961-2014), France (1970-2014), Greece (1973-2014), Ireland (1971-2014), Italy (1970-2014), the Netherlands (1969-2014), Portugal (1981-2014), Spain (1979-2014), Sweden (1971-2014), the UK (1970-2014), plus Canada (1964-2004), Japan (1972-2014), and the United States (1961-2014).

In order to control for the beginning of the $3^{\text {rd }}$ stage of the Economic and Monetary Union, and the launching of the euro, on the $1^{\text {st }}$ of January 1999 , we have used a dummy variable that takes the value one from 1999 onwards inclusively. Such variable is statistically significant in several countries, notably regarding the long-term interest rate. ${ }^{2}$

Table 1 summarises the country-specific investment series while Figure 1 plots the 17 country average private and public investment-to-GDP ratios.

[Table 1]

[Figure 1]

In order to estimate our VAR for each country, we use information for the following data series: GDP at current market prices; price deflator of GDP; general government gross fixed capital formation at current prices, used as public investment; gross fixed capital formation (GFCF) of the private sector at current prices, used as private investment; taxes (including direct taxes, indirect taxes and social contributions); nominal long-term interest rate and the consumer price index.

GDP, taxes and investment variables are used in real values using the price deflator of GDP and the price deflator of the GFCF of the total economy. ${ }^{3}$ A real ex-post interest rate is computed using the consumer price index inflation rate. All data are taken from the European Commission Ameco database. ${ }^{4}$

\footnotetext{
${ }^{2}$ To control for the reunification process a dummy was also used for the case of Germany in 1991.

${ }^{3}$ Due to the lack of information on a price deflator for private investment, we use the same deflator to compute both public and private investment variables.

${ }^{4}$ The data sources are mentioned in Appendix 2.
} 
All variables enter the VAR as logarithmic growth rates, except the interest rate, where first differences of original values were taken. Moreover, the first differenced variables are mostly stationary, I (0) time series. Table 2 shows unit root test statistics.

[Table 2]

\section{Crowding-out and crowding-in effects}

Figures 2 and 3 show the impulse response functions from a one standard deviation shock to public investment and to private investment, respectively for the cases of Portugal and Ireland, as an illustration. It is clear from these charts that a public investment shock may have a different impact on private investment, implying a crowding-in effect in Portugal and crowding-out effect in Ireland.

[Figure 2]

[Figure 3]

Table 3 summarises the results for the long-run elasticities, the marginal productivity rates and the macroeconomic rates of return, partial and total, for both public and private investment for the period 1960-2014 for the 17 country set.

\section{[Table 3]}

Figure 4 displays on the vertical axis the marginal effects of public investment on private investment, allowing the assessment of the existence of crowding-in or crowding-out effects of public investment on private investment. As Figure 4 shows, public investment has a positive growth impact in 12 countries and negative one on 5 countries (Finland, UK, Sweden, Japan, and Canada). Moreover, public investment has a crowding-in effect on private investment in 11 of the 17 countries analysed. Of the six countries in which public investment crowds-out effect on private investment, two (Belgium and Ireland) experience a slight output expansion, while Finland, Canada, Sweden, the UK, show a contractionary effect.

[Figure 2]

[Figure 3] 
In a similar way we report in Figure 5 the effects of private investment on output and the existing crowding-in or crowding-out effects of private investment on public investment. Moreover, it is also possible to conclude that private investment has an expansionary effect on output for all 17 countries in the sample. Figure 3 also reveals that private investment crowdsin public investment for most countries in the sample, and crowds-out public investment in the cases of Belgium, and Sweden, This is an outcome quite in line with the results reported by Afonso and St. Aubyn (2009), for the period 1960-2004.

Table 4 provides a comparison between the results in this paper, for the period 1960-2014 and the results of Afonso and St. Aubyn (2009) covering the period 1960-2004. Therefore, the current study encompasses the period of 2008-2009 economic and financial crisis.

[Table 4]

For the cases where such comparison is feasible, Table 4 makes it possible to draw some additional results, for the period 1960-2014 vis-à-vis the period before the crisis. Regarding the marginal productivity of public investment, there was an increase in nine countries, while the marginal productivity of private investment increased in seven cases between the two periods. In around half of the countries, the increase (decrease) in the marginal productivity of private or public investment takes place alongside the reduction (increase) in the investmentto-GDP ratio. In the remaining cases that parallel is not present given the compensating opposite effect (vis-à-vis the investment ratio) of the change in respective the output elasticity to investment.

Therefore, the total rate of return of public investment increased in three countries (Portugal, Denmark, and Greece) and decreased in seven countries (Austria, Germany, Spain, Finland, the UK, Italy and the Netherlands). In addition, the total rate of return of private investment increased in five countries (Belgium, Germany, Denmark, France, and Ireland) and decreased in all the other countries but the USA, where it remained essentially unchanged.

\section{Conclusion}

In this paper we have used a VAR analysis for 17 countries OECD between 1960 and 2014 to assess the effects of public and private investment in terms of economic growth, crowding out and crowding in. In that context, we also compute public and private investment 
macroeconomic rates of return, and assessed the potential effect of the 2008 economic and financial crisis.

Our results for the effects of investment shocks show that;

i) public investment had a positive growth effect in most countries;

ii) public investment had a contractionary effect on output in five cases (Finland, UK, Sweden, Japan, and Canada);

iii) positive public investment impulses led to a decline in private investment (crowdingout) in six countries (Belgium, Ireland, Finland, Canada, Sweden, the UK);

iv) public investment had a crowding-in effect on private investment in the remainder 11 countries;

v) private investment had a positive growth effect in all countries;

vi) private investment crowds-out public investment in the cases of Belgium, and Sweden;

vii) private investment crowds-in public investment in the remainder 15 countries.

Moreover, the partial rate of return of public investment is mostly positive, with the exceptions of Austria, Belgium, and Ireland, while the total rate of return of public investment is also negative in Germany and in the UK. On the other hand, the partial rate of return of private investment is only negative in Greece and marginally in Belgium, being the total rate of return of private investment negative for Belgium, Greece, and the UK.

\section{References}

Abiad, A., Furceri, D., Topalova, P. (2015). "The Macroeconomic Effects of Public Investment: Evidence from Advanced Economies", IMF WP/15/95.

Afonso, A., Jalles, J. (2015). "How does fiscal policy affect investment? Evidence from a large panel", International Journal of Finance and Economics, 20 (4), 310-327.

Afonso, A., St. Aubyn, M. (2009). "Macroeconomic Rates of Return of Public and Private Investment: Crowding-in and Crowding-out Effects", Manchester School, 77 (S1), 21-39.

Afonso, A., St. Aubyn, M. (2010). "Public and Private Investment Rates of Return: Evidence for Industrialised Countries”, Applied Economics Letters, 17 (9), 839 - 843.

Brückner, M., Tuladhar, A (2014). "Local Government Spending Multipliers and Financial Distress: Evidence from Japanese Prefectures”, Economic Journal, 124 (581), 1279_ 1316.

Cavalcanti, C., Merrero, G., Le, T. (2014). "Measuring the Impact of Debt-Financed Public Investment”, World Bank, Policy Research Working Paper No. 6766. 
Dreger, C., Reimers, H., (2014). "On the relationship between public and private investment in the euro area. DIW discussion paper 1365.

EC (2015). "Making the best use of the flexibility within the existing rules of the Stability and Growth Pact”, COM(2015) 12 final, Strasbourg, 13.1.2015, COM(2015) 12 final.

IMF (2014). "Is it time for an infrastructure push? The macroeconomic effects of public investment", IMF World Economic Outlook, October.

Le Moigne, M., Saraceno, F., Villemot, S. (2016). "Probably Too Little, Certainly Too Late. An Assessment of the Juncker Investment Plan”, OFCE WP 2016-10.

Pereira, A. (2000). Is All Public Capital Created Equal? Review of Economics and Statistics $82(3), 513-518$.

Pina, A., St. Aubyn, M. (2005). Comparing macroeconomic returns on human and public capital: An empirical analysis of the Portuguese case (1960-2001). Journal of Policy Modelling 27, 585-598.

Pina, A., St. Aubyn, M. (2006). How should we measure the return on public investment in a VAR? Economics Bulletin 8(5), 1-4.

TEU (2012). Consolidate version of the Treaty on the functioning of the European Union, Official Journal of the European Union, 26.10.2012

Turrini, A. (2004). "Public investment and the EU fiscal framework", European Economy. European Commission Economic Papers, $n^{\circ} 202$, May.

$\mathrm{Xu}, \mathrm{X}$., Yan, Y. (2014). "Does government investment crowd out private investment in China?” Journal of Economic Policy Reform, 17 (1), 1-12. 


\section{Appendix 1 -The analytics of the macro rates of return}

We compute the long-run accumulated elasticity of $Y$ with respect to public investment, $I p u b$, from the accumulated impulse response functions (IRF) of the VAR, as

$$
\varepsilon_{\text {Ipub }}=\frac{\Delta \log Y}{\Delta \log \text { Ipub }} .
$$

The long-term marginal productivity of public investment is given by

$$
\text { MPIpub } \equiv \frac{\Delta Y}{\Delta I p u b}=\varepsilon_{\text {Ipub }} \frac{Y}{I p u b} .
$$

The partial-cost dynamic feedback rate of return of public investment, $r_{l}$, is the solution for:

$$
\left(1+r_{1}\right)^{20}=\text { MPIpub } .
$$

The long-term accumulated elasticity of $Y$ with respect to Ipriv can also be derived from accumulated IRF in a similar way:

$$
\varepsilon_{\text {Ipriv }}=\frac{\Delta \log Y}{\Delta \log \text { Ipriv }},
$$

and the long-term marginal productivity of private investment is given by

$$
\text { MPIpriv } \equiv \frac{\Delta Y}{\Delta \text { Ipriv }}=\varepsilon_{\text {Ipriv }} \frac{Y}{\text { Ipriv }} .
$$

Therefore, the marginal productivity of total investment, $M P T I$, is as follows:

$$
M P T I=\frac{\Delta Y}{\Delta I p u b+\Delta \text { Ipriv }}=\frac{1}{M P I p u b^{-1}+\text { MPIpriv }^{-1}}
$$

And the rate of return of total investment, from an impulse to public investment, $r_{2}$, is the solution for:

$$
\left(1+r_{2}\right)^{20}=\text { MPTI }
$$




\title{
Appendix 2 - Data sources
}

\author{
Original series
}

Ameco codes

Gross Domestic Product at current market prices, thousands national currency. 1.0.0.0.UVGD

Price deflator of Gross Domestic Product, national currency, 1995 = 100.

3.1.0.0.PVGD

Gross fixed capital formation at current prices; general government, national 1.0.0.0.UIGG currency.

Gross fixed capital formation at current prices; private sector, national 1.0.0.0.UIGP currency.

Price deflator gross fixed capital formation; total economy, national currency; 3.1.0.0.PIGT $1995=100$.

Nominal long-term interest rates - \%

1.1.0.0.ILN

National consumer price index $-1995=100$

3.0.0.0.ZCPIN

Current taxes on income and wealth (direct taxes); general government - 1.0.0.0.UTYGF;

National currency, current prices

1.0.0.0.UTYG

Taxes linked to imports and production (indirect taxes); general government - 1.0.0.0.UTVGF;

National currency, current prices

1.0.0.0.UTVG

Social contributions received; general government - National currency, current

1.0.0.0.UTSGF;

prices

1.0.0.0.UTSG

Note: series from the EC AMECO database, April 2015. 
Figure 1 - Private and public investment-to-GDP ratios, average of all countries $1 \mathrm{a}$ - Private investment (\% of GDP)

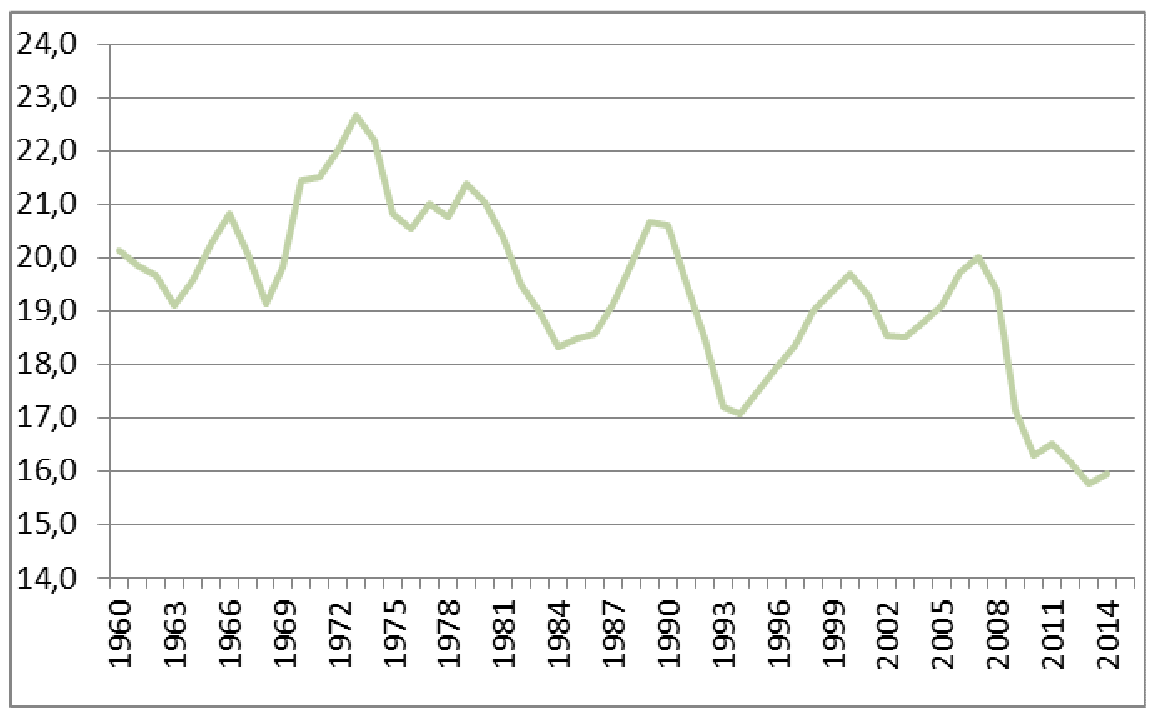

$1 \mathrm{~b}-$ Public investment (\% of GDP)

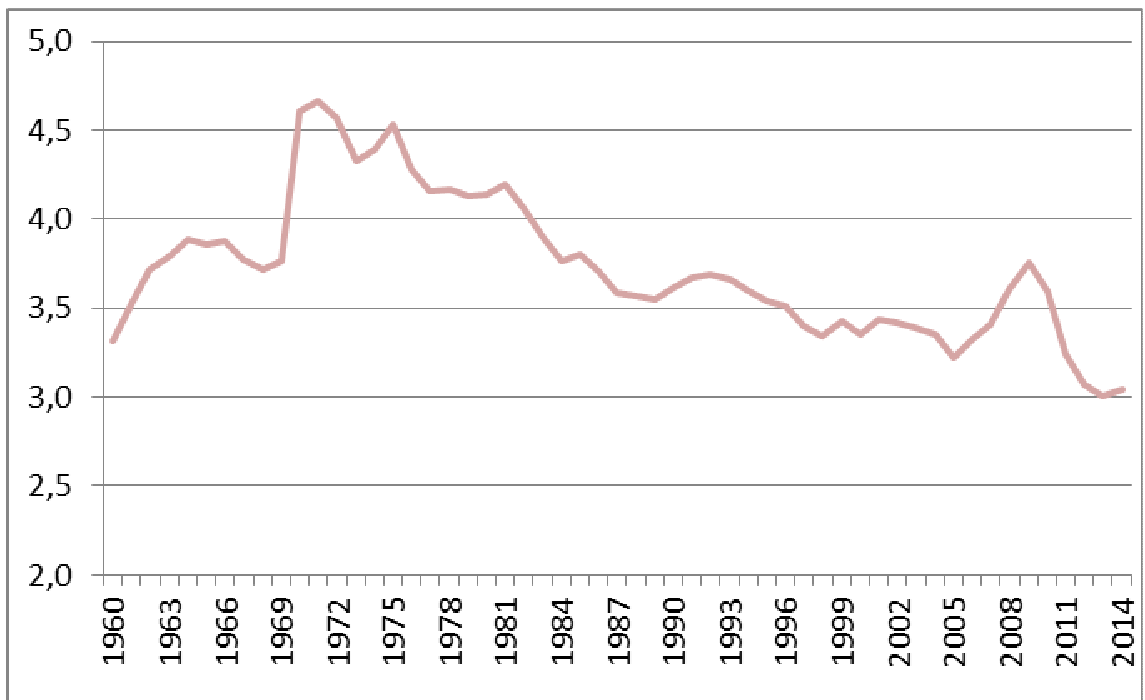


Figure 2 - Impulse response functions, Portugal (1981-2014)

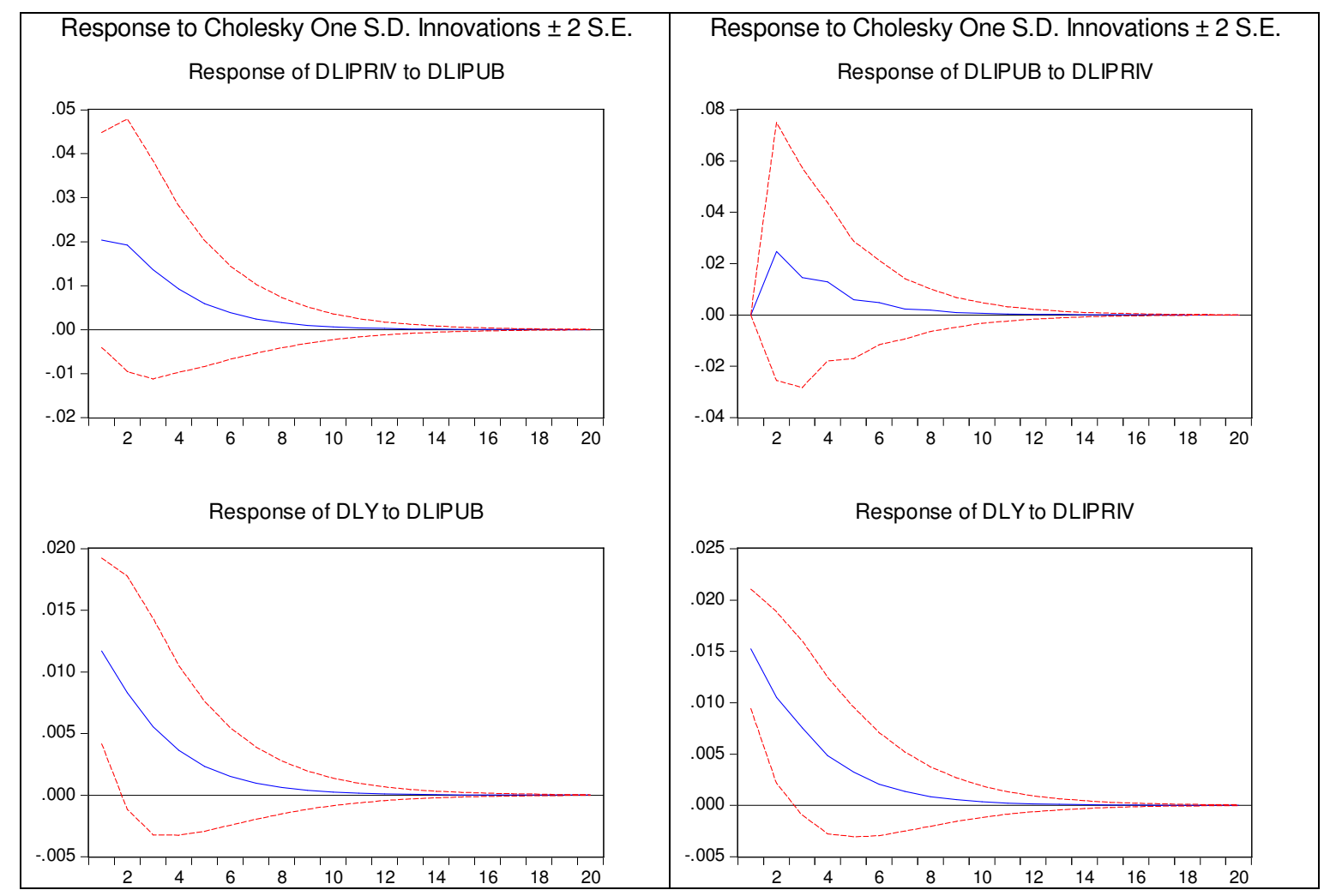

Figure 3 - Impulse response functions, Ireland (1971-2014)

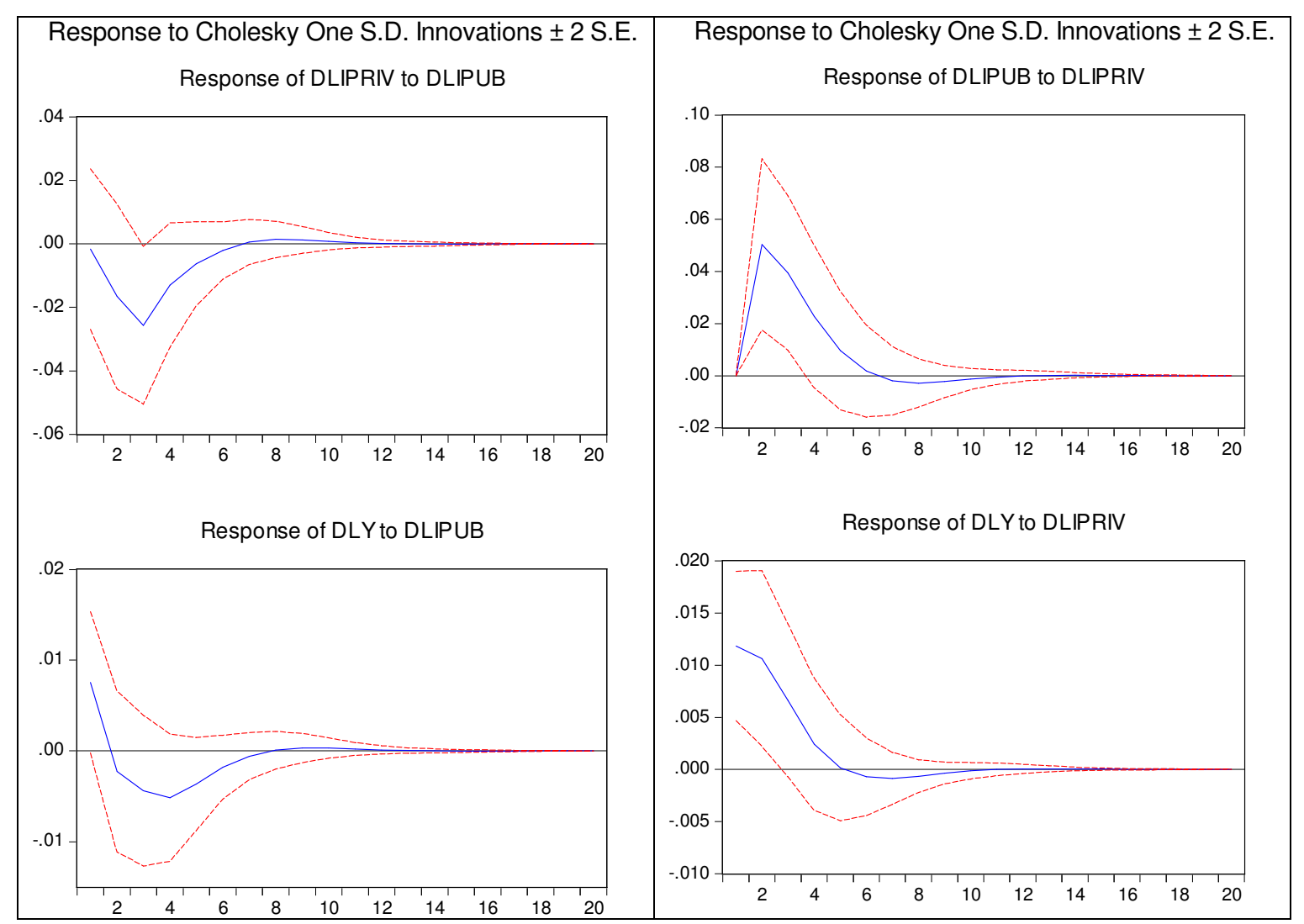


Figure 4 - Public investment: marginal productivity (horizontal) and marginal effect on private investment (vertical), (1960-2014)

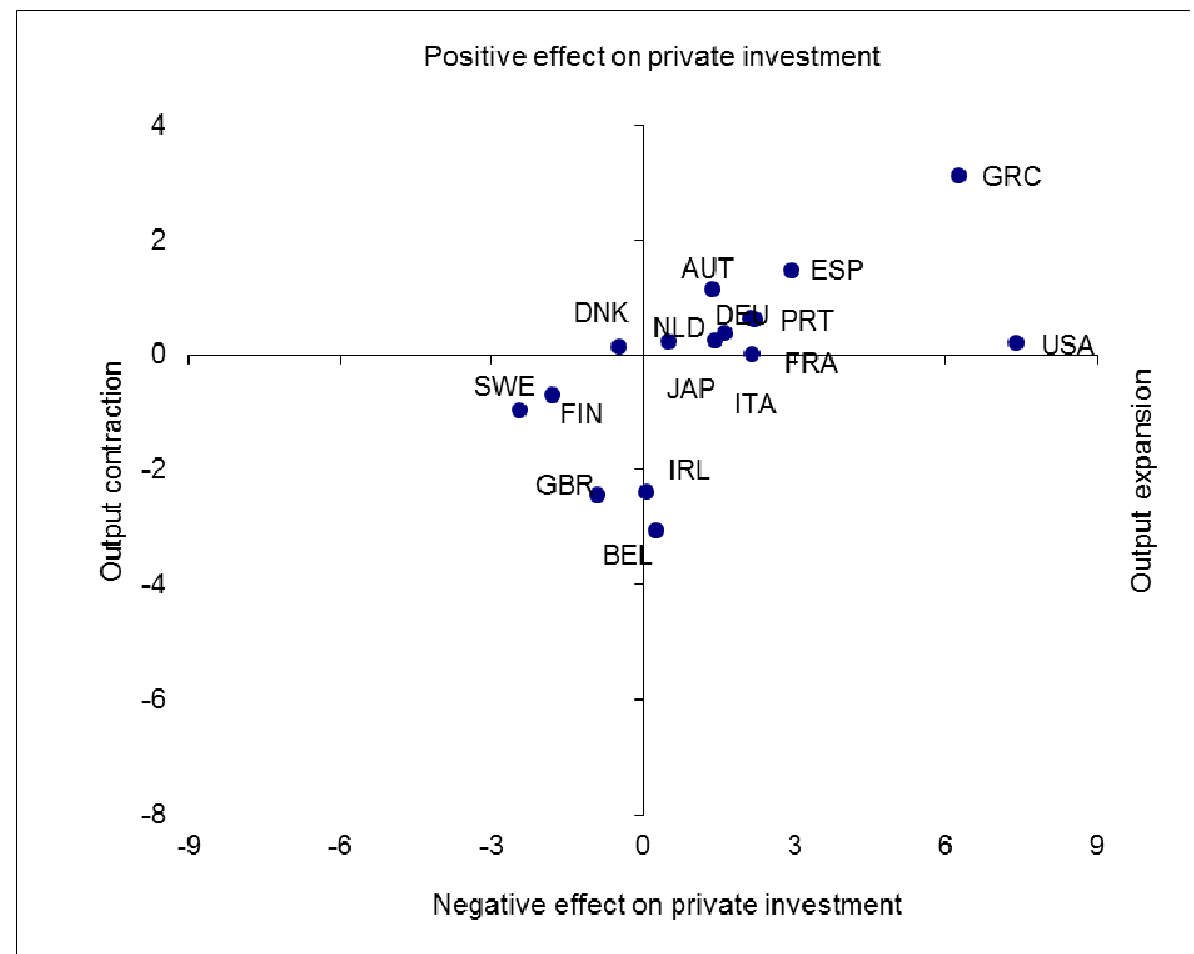

Note: AUT - Austria; BEL - Belgium; CAN - Canada; DEU - Germany; DNK - Denmark; ESP - Spain; FIN - Finland; FRA France; GBR - United Kingdom; GRC - Greece; IRL - Ireland; ITA - Italy; JAP - Japan; NLD - Netherlands; PRT - Portugal; SWE - Sweden; USA - United States.

Figure 5 - Private investment: marginal productivity (horizontal) and marginal effect on public investment (vertical), (1960-2014)

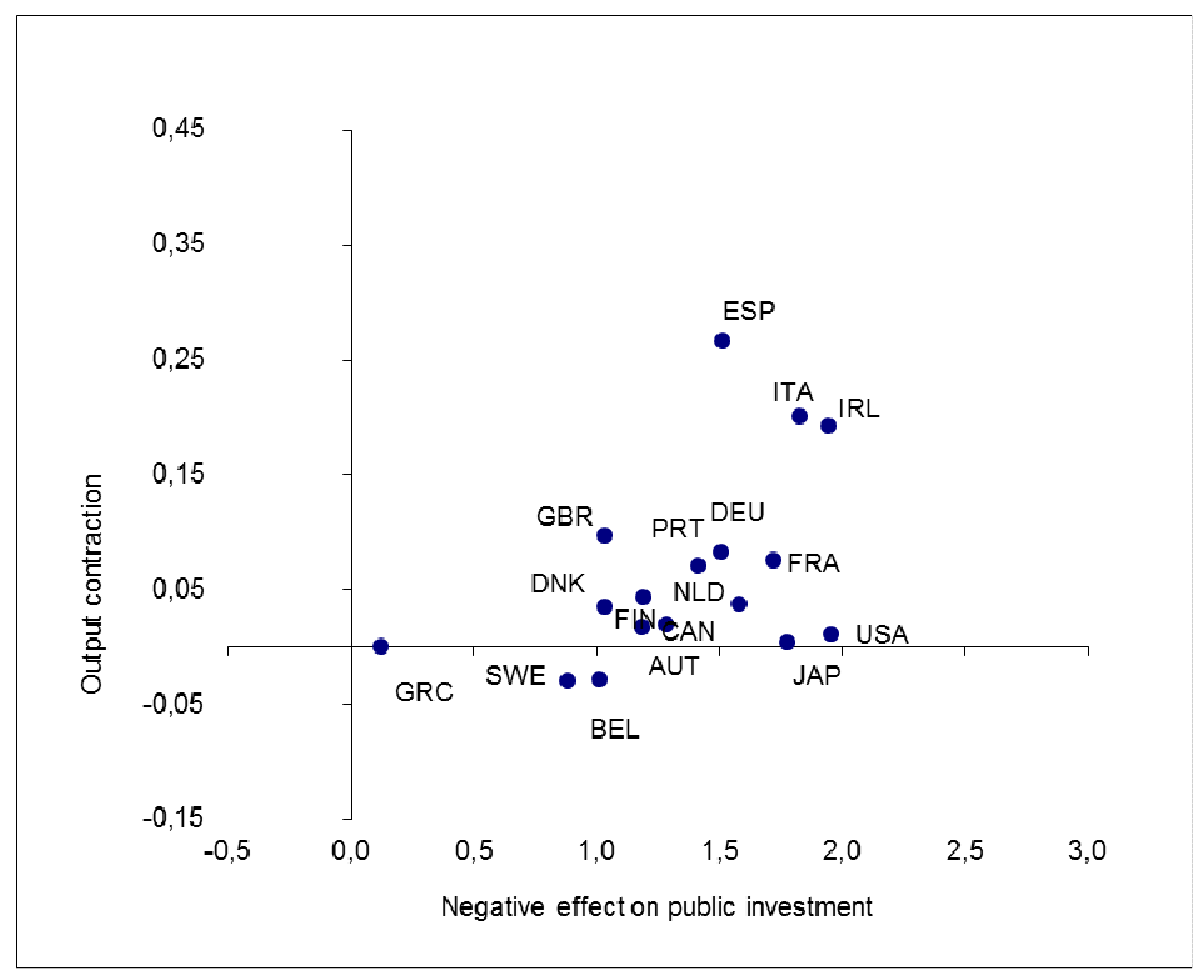

Note: see Figure 4. 
Table 1 - Public and private investment -to-GDP ratios

\begin{tabular}{lcccccccc}
\hline & \multicolumn{3}{c}{ Public investment-to-GDP ratios } & \multicolumn{3}{c}{ Private investment-to-GDP ratios } \\
\hline & 1970 & 1980 & 2010 & $1960-14$ & 1970 & 1980 & 2010 & $1960-14$ \\
\hline AUT & 4,7 & 4,2 & 3,2 & 3,5 & 19,7 & 20,2 & 18,4 & 20,1 \\
BEL & 4,8 & 5,3 & 2,2 & 2,7 & 22,3 & 19,7 & 20,1 & 19,3 \\
DEU & 4,8 & 3,7 & 2,3 & 2,8 & 21,5 & 19,5 & 17,0 & 19,0 \\
DNK & 4,7 & 3,8 & 3,3 & 3,1 & 20,0 & 16,6 & 14,9 & 17,5 \\
ESP & 2,9 & 2,1 & 4,7 & 3,5 & 23,4 & 20,3 & 18,3 & 20,1 \\
FIN & 4,2 & 4,3 & 3,7 & 4,1 & 23,5 & 23,0 & 18,2 & 20,6 \\
FRA & 4,9 & 4,1 & 4,1 & 4,2 & 20,7 & 20,2 & 17,9 & 18,2 \\
GBR & 6,2 & 3,4 & 3,2 & 2,8 & 17,4 & 18,2 & 12,8 & 16,9 \\
GRC & 2,9 & 2,2 & 3,2 & 3,1 & 25,4 & 29,2 & 14,0 & 19,2 \\
IRL & 4,2 & 5,7 & 3,4 & 3,2 & 19,3 & 23,3 & 12,4 & 17,8 \\
ITA & 3,5 & 3,8 & 2,9 & 3,2 & 21,7 & 21,8 & 17,0 & 18,3 \\
NLD & 6,3 & 4,7 & 4,1 & 4,2 & 22,7 & 18,5 & 15,6 & 18,0 \\
PRT & 2,4 & 4,6 & 5,3 & 3,3 & 21,9 & 24,4 & 15,3 & 21,1 \\
SWE & 8,3 & 5,4 & 4,5 & 4,9 & 18,6 & 17,7 & 17,7 & 17,8 \\
CAN & 3,9 & 2,9 & & 2,8 & 17,0 & 19,9 & & 17,5 \\
JAP & 4,8 & 5,7 & 3,3 & 4,6 & 32,2 & 25,8 & 16,7 & 22,2 \\
USA & 5,2 & 4,3 & 4,1 & 4,1 & 15,9 & 19,1 & 13,9 & 17,3 \\
\hline Max & 8,3 & 5,7 & 5,3 & 4,9 & 32,2 & 29,2 & 20,1 & 22,2 \\
Min & 2,4 & 2,1 & 2,2 & 2,7 & 15,9 & 16,6 & 12,4 & 16,9 \\
\hline SOurce
\end{tabular}

Source: EC, AMECO Database, updated on April 2015.

Table 2 - Unit root tests, variables in first differences:

Augmented Dickey-Fuller test statistics

\begin{tabular}{|c|c|c|c|c|c|c|c|c|c|c|}
\hline & \multicolumn{2}{|c|}{$\operatorname{dlog}(Y)$} & \multicolumn{2}{|c|}{ dlog(Ipub) } & \multicolumn{2}{|c|}{ dlog(Ipriv) } & \multicolumn{2}{|c|}{$\mathrm{d} \log (\operatorname{tax})$} & \multicolumn{2}{|c|}{ dir } \\
\hline & t-Statistic & $\begin{array}{l}\text { critical } \\
\text { value }\end{array}$ & $\begin{array}{c}\mathrm{t}- \\
\text { Statisti } \\
\mathrm{c}\end{array}$ & $\begin{array}{l}\text { critical } \\
\text { value }\end{array}$ & $\begin{array}{c}\mathrm{t}- \\
\text { Statistic }\end{array}$ & $\begin{array}{l}\text { critical } \\
\text { value }\end{array}$ & $\begin{array}{c}\mathrm{t}- \\
\text { Statistic }\end{array}$ & $\begin{array}{l}\text { critical } \\
\text { value }\end{array}$ & $\begin{array}{c}\mathrm{t}- \\
\text { Statistic }\end{array}$ & $\begin{array}{c}\text { critical } \\
\text { value }\end{array}$ \\
\hline Austria & -5.09 & -3.56 & -6.44 & -3.56 & -6.21 & -3.56 & -4.50 & -3.56 & -9.03 & -3.57 \\
\hline Belgium & $-5-03$ & -3.56 & -5.88 & -3.59 & -4.89 & -3.59 & -4.02 & -5.59 & -9.34 & -3.56 \\
\hline Denmark & -5.28 & -3.56 & -6.37 & -3.59 & -4.99 & -3.60 & -5.51 & -3.59 & -10.61 & -3.56 \\
\hline Finland & -4.55 & -3.56 & -7.48 & -3.59 & -4.29 & -3.59 & -5.53 & -3.56 & -6.77 & -3.56 \\
\hline France & -3.38 & $-2.92 \$$ & -4.62 & -3.59 & -4.36 & -3.59 & -4.41 & -3.59 & -8.40 & -3.56 \\
\hline Germany & -5.68 & -3.56 & -4.46 & -3.59 & -4.84 & -3.59 & -5.57 & -3.59 & -9.35 & -3.56 \\
\hline Greece & $-3.57 \mathrm{a}$ & $-3.50 \$$ & -5.87 & -3.59 & -4.86 & -3.59 & -4.57 & -3.59 & -7.23 & -3.56 \\
\hline Ireland & -3.66 & -3.56 & -3.79 & -3.59 & -4.37 & -3.59 & -5.33 & -3.59 & -6.56 & -3.56 \\
\hline Italy & $-7.33 \mathrm{a}$ & -4.14 & -6.47 & -4.19 & -5.06 & -4.19 & -6.99 & -4.19 & -6.55 & -4.14 \\
\hline Netherlands & -3.58 & -3.56 & -5.58 & -3.59 & -4.51 & -3.59 & -5.42 & -3.59 & -10.17 & -3.56 \\
\hline Portugal & -3.42 & $-2.92 \$$ & -5.56 & -3.59 & -5.45 & -3.59 & -5.42 & -3.59 & -8.96 & -3.56 \\
\hline Spain & -3.21 & $-2.92 \$$ & -4.50 & -3.59 & -3.72 & -3.59 & -4.30 & -3.59 & -6.87 & -3.63 \\
\hline Sweden & -5.49 & -3.56 & -6.93 & -3.59 & -4.32 & -3.59 & -4.39 & -3.59 & -12.04 & -3.56 \\
\hline UK & -5.17 & -3.56 & -7.95 & -3.59 & -4.93 & -3.59 & -5.06 & -3.59 & -9.60 & -3.56 \\
\hline Canada & -4.10 & -3.56 & -5.39 & -3.59 & -4.23 & -3.64 & -4.82 & -3.61 & -7.11 & -3.56 \\
\hline Japan & $-5.62 \mathrm{a}$ & -3.56 & -4.72 & -3.59 & -4.89 & -4.18 & -4.20 & -3.59 & -4.29 & -3.56 \\
\hline US & -5.04 & -3.56 & $-3.40 \$$ & -2.93 & -4.12 & -3.59 & -5.50 & -3.59 & -7.09 & -3.56 \\
\hline
\end{tabular}

Note: critical values are for $1 \%$ level unless otherwise mentioned.

\# - 10\% level; \$ - 5\% level. a - with constant and trend 
Table 3 - Long-run elasticities, marginal productivity and rates of return (1960-2014)

\begin{tabular}{lccccc}
\hline \multicolumn{5}{c}{ a) Impulse on public investment } \\
\hline $\begin{array}{c}\text { Output } \\
\text { elasticity }\end{array}$ & MPIpub & $\begin{array}{c}\text { Partial } \\
\text { rate of } \\
\text { return (\%) }\end{array}$ & MPTI & $\begin{array}{c}\text { Total rate } \\
\text { of return } \\
(\%)\end{array}$ \\
\hline Austria & 0.019 & 0.525 & -3.17 & 0.427 & -4.16 \\
Belgium & 0.007 & 0.275 & -6.25 & -0.134 & \\
Denmark & 0.045 & 1.436 & 1.83 & 1.148 & 0.69 \\
Finland & -0.073 & -1.799 & & -5.977 & \\
France & 0.091 & 2.170 & 3.95 & 2.145 & 3.89 \\
Germany & 0.039 & 1.376 & 1.61 & 0.645 & -2.17 \\
Greece & 0.191 & 6.246 & 9.59 & -0.055 & 2.10 \\
Ireland & 0.002 & 0.078 & -12.00 & -0.055 & \\
Italy & 0.052 & 1.620 & 2.44 & 1.191 & 0.88 \\
Netherlands & 0.089 & 2.148 & 3.90 & 1.307 & 1.35 \\
Portugal & 0.073 & 2.231 & 4.09 & 1.383 & 1.64 \\
Spain & 0.102 & 2.949 & 5.56 & 1.192 & 0.88 \\
Sweden & -0.120 & -2.446 & & -52.819 & \\
United Kingdom & -0.026 & -0.909 & & 0.635 & -2.25 \\
\hline Canada & -0.315 & -11.115 & & 2.016 & 3.57 \\
Japan & -0.022 & -0.467 & & -0.409 & \\
United States & 0.302 & 7.396 & 10.52 & 6.193 & 9.55 \\
\hline
\end{tabular}

b) Impulse on private investment

\begin{tabular}{lccccc}
\hline & $\begin{array}{c}\text { Output } \\
\text { elasticity }\end{array}$ & MPIpriv & $\begin{array}{c}\text { Partial } \\
\text { rate of } \\
\text { return }(\%)\end{array}$ & MPTI & $\begin{array}{c}\text { Total rate } \\
\text { of return } \\
(\%)\end{array}$ \\
\hline Austria & 0.239 & 1.192 & 0.88 & 1.142 & 0.66 \\
Belgium & 0.170 & 0.883 & -0.62 & 0.910 & -0.47 \\
Denmark & 0.181 & 1.034 & 0.17 & 1.000 & 0.00 \\
Finland & 0.264 & 1.284 & 1.26 & 1.259 & 1.16 \\
France & 0.312 & 1.719 & 2.75 & 1.599 & 2.37 \\
Germany & 0.301 & 1.583 & 2.32 & 1.525 & 2.13 \\
Greece & 0.024 & 0.123 & -9.94 & 0.123 & -9.94 \\
Ireland & 0.326 & 1.830 & 3.07 & 1.523 & 2.13 \\
Italy & 0.355 & 1.943 & 3.38 & 1.630 & 2.47 \\
Netherlands & 0.254 & 1.412 & 1.74 & 1.320 & 1.40 \\
Portugal & 0.319 & 1.512 & 2.09 & 1.397 & 1.69 \\
Spain & 0.304 & 1.515 & 2.10 & 1.197 & 0.90 \\
Sweden & 0.179 & 1.010 & 0.05 & 1.040 & 0.20 \\
United Kingdom & 0.175 & 1.034 & 0.17 & 0.943 & -0.29 \\
\hline Canada & 0.208 & 1.189 & 0.87 & 1.168 & 0.78 \\
Japan & 0.395 & 1.779 & 2.92 & 1.773 & 2.91 \\
United States & 0.339 & 1.958 & 3.42 & 1.935 & 3.36 \\
\hline
\end{tabular}

Notes: na - not available. The rate of return cannot be computed in this case since the marginal productivity is negative. MPIpub - marginal productivity of public investment. MPIpriv - marginal productivity of private investment. MPTI - marginal productivity of total investment. We use the average of the GDP-to-investment ratios for the period 1960-2014 (or starting later, depending on data availability, see notably the sample sizes mentioned before). 
Table 4 - Marginal productivity and rates of return, 1960-2004 vs 1960-2014

\begin{tabular}{|c|c|c|c|c|c|c|c|}
\hline & & \multicolumn{3}{|c|}{ Effect of public investment shock } & \multicolumn{3}{|c|}{ Effect of private investment shock } \\
\hline & & $\begin{array}{l}\text { Marginal } \\
\text { productivity } \\
\text { of public } \\
\text { investment }\end{array}$ & $\begin{array}{l}\text { Marginal } \\
\text { IPUB } \\
\text { effect on } \\
\text { IPRIV } \\
\end{array}$ & $\begin{array}{l}\text { Total rate of } \\
\text { return (with } \\
\text { feedback } \\
\text { effects), \% }\end{array}$ & $\begin{array}{l}\text { Marginal } \\
\text { productivity } \\
\text { of private } \\
\text { investment }\end{array}$ & $\begin{array}{l}\text { Marginal } \\
\text { IPRIV } \\
\text { effect on } \\
\text { IPUB } \\
\end{array}$ & $\begin{array}{l}\text { Total rate of } \\
\text { return (with } \\
\text { feedback } \\
\text { effects), \% }\end{array}$ \\
\hline \multirow[t]{2}{*}{ PRT } & I & 5.18 & 5.21 & $-0.9 \%$ & 1.35 & 0.16 & $1.4 \%$ \\
\hline & II & 2.23 & 0.61 & $1.6 \%$ & 1.51 & 0.27 & $0.9 \%$ \\
\hline \multirow[t]{2}{*}{ AUT } & I & 1.60 & 2.45 & $-3.8 \%$ & 1.45 & 0.07 & $1.5 \%$ \\
\hline & II & 0.52 & 0.23 & $-4.2 \%$ & 1.19 & 0.04 & $0.7 \%$ \\
\hline \multirow[t]{2}{*}{ BEL } & I & -0.43 & -3.02 & $-7.4 \%$ & 0.86 & -0.03 & $-0.6 \%$ \\
\hline & II & 0.27 & -3.06 & na & 0.88 & -0.03 & $-0.5 \%$ \\
\hline \multirow[t]{2}{*}{ DEU } & I & 1.72 & 0.53 & $0.6 \%$ & 1.47 & 0.03 & $1.8 \%$ \\
\hline & II & 1.38 & 1.13 & $-2.2 \%$ & 1.58 & 0.04 & $2.1 \%$ \\
\hline \multirow[t]{2}{*}{ DNK } & I & 2.54 & 1.54 & $0.0 \%$ & 0.95 & 0.04 & $-0.5 \%$ \\
\hline & II & 1.44 & 0.25 & $0.7 \%$ & 1.03 & 0.03 & $0.0 \%$ \\
\hline \multirow[t]{2}{*}{ FIN } & I & 0.44 & 0.34 & $-5.4 \%$ & 1.06 & 0.02 & $0.2 \%$ \\
\hline & II & -1.80 & -0.70 & na & 1.28 & 0.02 & $0.2 \%$ \\
\hline \multirow[t]{2}{*}{ ESP } & I & 2.66 & 0.72 & $2.2 \%$ & 1.56 & 0.18 & $1.4 \%$ \\
\hline & II & 2.95 & 1.47 & $0.9 \%$ & 1.52 & 0.27 & $0.9 \%$ \\
\hline \multirow[t]{2}{*}{ FRA } & I & 1.53 & -0.56 & $6.5 \%$ & 1.35 & 0.06 & $1.2 \%$ \\
\hline & II & 2.17 & 0.01 & $3.9 \%$ & 1.72 & 0.08 & $2.4 \%$ \\
\hline \multirow[t]{2}{*}{ GBR } & I & -1.62 & -2.03 & $2.3 \%$ & 1.84 & 0.09 & $2.7 \%$ \\
\hline & II & -0.91 & -2.43 & $-2.2 \%$ & 1.03 & 0.10 & $-0.3 \%$ \\
\hline \multirow[t]{2}{*}{ GRC } & I & 2.39 & 1.58 & $-0.4 \%$ & 0.91 & -0.08 & $0.0 \%$ \\
\hline & II & 6.25 & 3.12 & $2.1 \%$ & 0.12 & 0.00 & $-9.9 \%$ \\
\hline \multirow[t]{2}{*}{ IRL } & I & -1.60 & -2.77 & $-0.5 \%$ & 1.85 & 0.30 & $1.8 \%$ \\
\hline & II & 0.08 & -2.40 & na & 1.83 & 0.20 & $2.1 \%$ \\
\hline \multirow[t]{2}{*}{ ITA } & I & 0.51 & -0.80 & $4.8 \%$ & 1.11 & -0.34 & $2.7 \%$ \\
\hline & II & 1.62 & 0.36 & $0.9 \%$ & 1.94 & 0.19 & $2.5 \%$ \\
\hline \multirow[t]{2}{*}{ NLD } & I & -2.72 & -2.35 & $3.6 \%$ & 1.78 & 0.07 & $2.6 \%$ \\
\hline & II & 2.15 & 0.64 & $1.3 \%$ & 1.41 & 0.07 & $1.4 \%$ \\
\hline \multirow[t]{2}{*}{ SWE } & I & 0.13 & 0.40 & $-11.3 \%$ & 1.08 & -0.09 & $0.9 \%$ \\
\hline & II & -2.45 & -0.95 & na & 1.01 & -0.03 & $0.2 \%$ \\
\hline \multirow[t]{2}{*}{ CAN } & I & -2.31 & -2.30 & $2.9 \%$ & 1.28 & 0.03 & $1.1 \%$ \\
\hline & II & -11.12 & -6.52 & $3.6 \%$ & 1.19 & 0.02 & $0.8 \%$ \\
\hline \multirow[t]{2}{*}{ JAP } & I & 0.01 & -0.99 & $0.8 \%$ & 3.09 & 0.43 & $3.9 \%$ \\
\hline & II & -0.47 & 0.14 & na & 1.78 & 0.00 & $2.9 \%$ \\
\hline \multirow[t]{2}{*}{ USA } & I & 1.83 & -2.98 & na & 2.03 & 0.06 & $3.3 \%$ \\
\hline & II & 7.40 & 0.19 & $9.5 \%$ & 1.96 & 0.01 & $3.4 \%$ \\
\hline
\end{tabular}

Notes: I - 1960-2004 (Afonso and St. Aubyn, 2009); II - 1960-2014. na - not available. The rate of return cannot be computed in this case since the marginal productivity is negative. IPUB - public investment; IPRIV - private investment. AUT - Austria; BEL - Belgium; CAN - Canada; DEU - Germany; DNK - Denmark; ESP - Spain; FIN - Finland; FRA - France; GBR - United Kingdom; GRC - Greece; IRL - Ireland; ITA - Italy; JAP Japan; NLD - Netherlands; PRT - Portugal; SWE - Sweden; USA - United States. 